\title{
Joanna Szwabe, Odbiór komunikatu jako zadanie poznawcze. Ujęcie pragmatyczno-kognitywne, Wydawnictwo Naukowe UAM, Poznań 2008, ss. 151
}

Problem komunikacji językowej można bez wątpienia uznać za tyleż ważny, co modny. Rozmaicie rozumiana interdyscyplinarność zakłada bowiem, że mechanizmy komunikacyjne nie są wyłącznie domeną prostej transmisji na osi nadawczo-odbiorczej, że nie sprowadzają się do przesyłania tekstów tożsamych pod względem informacyjności. W tym sensie jak najbardziej słuszne wydaje się kluczowe założenie, przyjęte przez autorkę pracy Odbiór komunikatu jako zadanie poznawcze, że oto interpretacja czyniona przez odbiorcę w standardowej komunikacji sytuacyjnej nosi zawsze znamiona wieloczynnikowego zadania.

Wieloczynnikowość jest oczywiście typową refleksją dla ujęcia pragmatycznego i w tym rozumieniu wpisuje się doskonale $\mathrm{w}$ podjęte $\mathrm{w}$ książce zagadnienia. Zaakcentowanie jednak roli odbiorcy w procesie komunikacji stanowi zasadniczą wartość pracy - nie jest to bowiem dość częsty punkt widzenia badaczy.

Autorka na początku swojej pracy przypomina, że mijają ponad trzy dekady od momentu, gdy Paul Grice rozpoczął dociekanie istoty rozumienia niekodowanej postaci komunikatu. Kwestie intencji nadawcy, jego roli w projektowaniu (czy wręcz gwarantowaniu) odbioru zasłużyły już na stosowną bibliografię, gdy tymczasem odbiorca pozostawał na pozycji biernego dekodera inwencji nadawczej. Dlatego też we wstępie autorka podkreśla: „Podjęcie kwestii receptywnej strony komunikacji wyznacza trojakie, wzajemnie powiązane cele niniejszej pracy, mianowicie ustalenie: co jest do odebrania (struktura komunikatu), jak intencje i presupozycje odbiorcy kształtuja przebieg interpretacji, jakie dyspozycje pozwalają na dokonanie interpretacji tak zbudowanego komunikatu" (s. 7). 
W książce przyjęte zostały podstawowe założenia inferencyjnego modelu komunikacyjnego w ujęciu komentatorów idei Grice'owskich - Stevena Levinsona oraz Dana Sperbera i Deirdre Wilson. Wynika z tych założeń zdecydowanie, że zdarzenie odkodowania, w którym znaczenie zdania pokrywa się ze znaczeniem mówcy, jest idealizacją jeśli nie niemożliwą, to całkiem rzadką. Inferencja właśnie odgrywa tu zasadniczą rolę - co tym samym eksponuje odbiorce jako gwarancję toku rozmowy (komunikacji) w przypadku wadliwych predyspozycji mówcy. Co więcej, autorka stawia sobie za cel ustosunkowanie się krytyczne do tych ustaleń kognitywnych, które pozostawiają (niejako wbrew przekonaniu o istocie inferencji w komunikacji) w mocy kategorię odbiorcy w świetle typowego modelu telegraficznego ${ }^{1}$. Wydaje się zatem, że perspektywa pragmatyczno-kognitywna, którą Szwabe przyjmuje w swojej pracy, pozwala na wnioskowanie o bardzo skomplikowanym procesie odbioru komunikatu, z uwzględnieniem czynników wskazywanych przez lingwistykę, kognitywistykę i filozofię języka (co sugeruje recenzent wydawniczy).

Książka składa się z trzech części, poprzedzonych wstępem i zwieńczonych zakończeniem, bibliografią oraz aneksem. Pierwsza część dotyczy struktury komunikatu w modelu inferencyjnym i jest rzetelnym, a także zaskakująco dynamicznym opisem mechanizmu implikacji oraz zasady relewancji. Problem znaczenia mówcy zyskuje tu (jak zresztą w całej pracy) sporo ilustracji tekstowych, będących argumentami na obronę rekonstruowanych tez. Wśród sygnalizowanych (wciąż jeszcze zbyt mało zbadanych) problemów autorka wskazuje w niniejszej części tzw. mikroreguły gramatyczne, które zaobserwować można dzięki badaniom korpusowym autentycznego, konwersacyjnego materiału. Owe mikroreguły stanowiłyby podstawową motywację dla kategorii relewancji u odbiorcy, co jednak (jak słusznie podkreśla autorka) nie jest zasługą racjonalności czy optymalizacji. Odbiorcy bowiem moga również towarzyszyć przesłanki emocjonalne, zwłaszcza wówczas, gdy jedna z mikroreguł gramatycznych będzie na przykład oparta na nośnym kulturowo intertekście. Pozostaje zatem zgodzić się ze stwierdzeniem autorki, że dopiero wnikliwe badania materiałowe (ale wyłącznie o podstawach inferencyjnych) mogą dowieść jakiejkolwiek regularności w obrębie tego zagadnienia².

${ }^{1} \mathrm{Na}$ ten temat wypowiadali się także antropologowie komunikacji, zwracając uwagę na semantyczne ubóstwo prostego modelu nadawczo-odbiorczego. Parametry pragmatyczne domagają się bowiem uwzględnienia co najmniej kilku problemów wynikających ze stabilizacji znaczeń na drodze interpretowania. Zob. np. Y. Winkin, Antropologia komunikacji. Od teorii do badań terenowych, przeł. A. Karpowicz, Warszawa 2007.

${ }^{2}$ W tym miejscu można sobie pozwolić już na myśl, która jest ważna również dla konkluzji niniejszego szkicu recenzującego. Mikroreguły gramatyczne, jak i elementarny postulat relewancji jako zjawiska wspierającego odbiór komunikatu mogą mieć swoje konsekwencje także 
Część druga książki dotyczy ściśle odbioru komunikatu. Tutaj najmocniej sformułowana zostaje teza, że oto motywacją komunikacyjną odbiorcy - gwarancją jego aktywności i modyfikatorem przyjmowanej przez niego zasady relewancji - jest korzyść poznawcza. Nie oznacza to jednak, że odbiorca w modelu inferencyjnym nie jest postrzegany jako naiwny optymista. Dzieje się tak, ilekroć w myśl prostego rozumienia teorii relewancji (w obrębie którego działa silnie idea kluczowego intencjonalnego znaczenia nadawcy), odbiorca wyznacza sobie zadanie odnalezienia znaczenia mówcy³.

Zasada relewancji zakłada, że odbiorca w procesie komunikacji dąży do maksymalnych korzyści poznawczych przy minimalnym wysiłku, z czego wynika, że proces interpretacji motywowany jest spełnieniem właśnie wymogu relewancji. Bardzo ciekawe w tym kontekście są sytuacje specjalne, wśród których również znajduje się komunikacja literacka z odbiorca, który nie został precyzyjnie wybrany - jest stroną całkowicie przypadkową. Autorka podaje cztery specjalne typy zjawisk komunikacyjnych, dla których trzeba przyjąć modyfikowane ujęcie teorii relewancji (przez wzgląd na komplikowane zjawisko satysfakcji poznawczej): „(1) odbiór tekstu lub mowy niezwróconej do nikogo konkretnego (literatura, prasa, programy telewizyjne i radiowe, itp.); (2) odbiór tekstu bez adresata (np. pamiętnik); (3) odbiór poza wiedzą autora przekazu mówionego lub pisanego, skierowanego do kogoś innego (np. podsłuchana rozmowa); (4) odbiór tekstów i mowy, gdy słuchacz jest obserwatorem dialogu między innymi osobami (korespondencja na łamach prasy, symulowanie rozmowy w mediach)" (s. 81).

Wymienione sytuacje blokują proste rozumienie zasady relewancji choćby dlatego, że relacja nadawczo-odbiorcza nie jest bezpośrednia, cały zatem proces inferencji czerpie $\mathrm{z}$ owego zapośredniczenia (mniej czy bardziej konwencjonalnego).

w komunikacji literackiej. Problem ten nie jest w książce Szwabe omawiany, niemniej jednak zadanie poznawcze, jakie staje przed czytelnikiem tekstu literackiego, też w znacznym stopniu warunkowane jest dyspozycyjnością inferencyjną czytelnika. Mechanizm konstruowania interpretacji na podstawie implikowań wydaje się praktyką oczywistą choćby w świetle ustaleń przedstawicieli nowych nurtów w teorii literatury. Na przykład Stanley Fish, pisząc na temat dosłowności i podstaw interpretacyjnych (choć i on w tym miejscu nie rozważa problemu tekstu literackiego), wskazuje na tzw. interpretacyjny standard społeczny, który determinuje późniejsze, indywidualne procesy odbiorcze. Ów standard jest tu podobnie sankcjonowanym (czy tylko wspieranym) gramatycznie mechanizmem poznawczym. Zob. S. Fish, Zwykte okoliczności, język dosłowny, bezpośrednie akty mowy, to, co normalne, potoczne, oczywiste, zrozumiałe samo przez się i inne szczególne przypadki, w: idem, Interpretacja, retoryka, polityka. Eseje wybrane, red. A. Szahaj, Kraków 2008, s. 29-58.

${ }^{3}$ Bliska takiemu założeniu jest utopijna praktyka interpretacyjnego dociekania intencji autorskiej stosowana jako podwaliny skutecznego dekodowania tekstu literackiego. 
Autorka w ostatnim rozdziale tej części - po raz kolejny akcentując rolę odbiorcy jako konstytutywną w procesie interpretacji - charakteryzuje warunki powodzenia aktu komunikacji ze względu na motywację poznawczą odbior$c y^{4}$. Najbardziej istotnym wnioskiem wypływającym z poczynionych tu analiz jest przekonanie, że odbiorca (kompetentny - o czym mowa zwłaszcza w trzeciej części książki) nie jest ściśle zależny poznawczo od kompetencji i szczerości nadawcy (mówcy). Wydaje się, że właśnie te wątki najtrafniej określają sytuacje związane z komunikacją literacką, w której - jak wspomniano wcześniej - założenie intencji autorskiej stanowi typową potoczną idealizację ${ }^{5}$.

Część trzecia dotyczy kompetencji pragmatycznej - również postrzeganej w perspektywie motywacji odbiorczej. Kompetencja ta jest tu rozumiana jako „zdolność do konstruowania i rekonstruowania niekodowanego znaczenia komunikatów (implikatur, presupozycji, ustalania odniesienia wyrażeń deiktycznych i anaforycznych) oraz rozpoznawania pośrednich i bezpośrednich aktów mowy" (s. 107-108) i jako taka ma istotny wpływ na kwestie poznawcze. Zagadnieniem spornym w tym ujęciu pozostaje krytykowane założenie, że istnieją bezpośrednie akty mowy. W świetle maksymalizowanych dyspozycji odbiorczych założenie takie ma charakter idealizacyjny i chyba znów niemożliwe jest dowiedzenie słuszności bez stosownych analiz korpusowych ${ }^{6}$.

Ostatni rozdział trzeciej części pracy poświęcony został procesowi mentalizacji i zaburzeniom komunikacyjnym (schizofrenia, autyzm). Atrybucja stanów mentalnych jest tu przedstawiona jako istotny czynnik umożliwiający konstrukcję lub rekonstrukcję intencjonalnego nadawcy, czyli stanowi dowód na to, że diagnozując komplikacje w odbiorze, udaje się precyzyjnie badać przeszkody komunikacyjne (np. związane z niedyspozycją psychiczną).

Wątpliwości może budzić tu założenie, że kompetencja pragmatyczna jest niezależna od formy językowej oraz kulturowo uwarunkowanych konwencji prowadzenia dyskursu. Wydaje się, że zależność taka wynika z założenia, że nie istnieją bezpośrednie akty mowy (co nie unieważnia myślenia np. kategorią gatunków). Forma językowa wraz ze swoim intertekstualnym sztafażem

${ }^{4}$ Wypada tu jedynie zaproponować w miejsce sformułowania ,interes poznawczy” odbiorcy, określenie „motywacja poznawcza”, które zdaje się bardziej adekwatne do omawianej problematyki komunikacyjnej.

${ }^{5}$ Oczywiście, idealizacja ta pozostaje w ścisłym związku z poziomem wiedzy o kontekście np. historycznoliterackim czy teoretycznoliterackim, w związku także z ogólnym zaangażowaniem odbiorcy w kulturę (np. czy dany tekst jest podany w oryginale, czy tłumaczony na inny język). Problem intencji autorskiej wiąże się również z pośrednictwem w komunikacji literackiej, czyli wszystkimi możliwymi instancjami wewnętrznotekstowej sytuacji nadawczej.

${ }^{6} \mathrm{~W}$ tym sensie, rozwijana myśl cytowanego na początku książki Szwabe Wittgensteina mogłaby istotnie wzbogacić refleksję na temat relacji semantyki i pragmatyki. 
kulturowym może istotnie wpłynąć na procesy poznawcze odbiorcy zaangażowanego $\mathrm{w}$ proces interpretacji.

Poczynione w niniejszym szkicu uwagi mają przede wszystkim na celu podkreślenie tego, że książka Joanny Szwabe stanowi bardzo ważny głos w dyskusji na temat jakości komunikacyjnych. Podkreślenie roli odbiorcy to fundamentalne założenie dalszych badań nad odbiorem tekstów, w tym także tekstów literackich. W tym bowiem przypadku bardzo łatwo ulec obiecującemu modelowi telegraficznemu, który obwarowany jest szeregiem poznawczych idealizacji. Wydaje się, że na poziomie prymarnego odbioru tekstu literackiego dominują mechanizmy (warunkowane kompetencją pragmatyczną odbiorcy), które sytuują się po stronie aktywnego interpretacyjnie czytelnika. $\mathrm{W}$ tym sensie ustalenia poczynione przez autorkę mogą istotnie wpłynąc na kierunek rozwoju dyskusji nad komunikacją literacką. Dlatego bez wątpienia pionierska praca Joanny Szwabe zasługuje na uznanie i zachęca do dalszych, świadomie interdyscyplinarnych badań. 